\title{
Reconstruction of former channel systems in the northwestern Nile Delta (Egypt) based on corings and electrical resistivity tomography (ERT)
}

\author{
Marina Altmeyer $^{1}$, Martin Seeliger ${ }^{1}$, Andreas Ginau ${ }^{1}$, Robert Schiestl ${ }^{2}$, and Jürgen Wunderlich ${ }^{1}$ \\ ${ }^{1}$ Department of Physical Geography, Goethe University Frankfurt, Frankfurt a. M., 60438, Germany \\ ${ }^{2}$ Department of Ancient History, Ludwig Maximilian University of Munich, Munich, 80539, Germany
}

Correspondence: $\quad$ Marina Altmeyer (marina.altmeyer@gmx.de)

Relevant dates: $\quad$ Received: 30 September 2020 - Revised: 30 March 2021 - Accepted: 16 April 2021 Published: 18 June 2021

How to cite:

Altmeyer, M., Seeliger, M., Ginau, A., Schiestl, R., and Wunderlich, J.: Reconstruction of former channel systems in the northwestern Nile Delta (Egypt) based on corings and electrical resistivity tomography (ERT), E\&G Quaternary Sci. J., 70, 151-164, https://doi.org/10.5194/egqsj-70-151-2021, 2021.

Abstract:

The current state of research about ancient settlements within the Nile Delta allows the hypothesizing of fluvial connections to ancient settlements all over the Nile Delta. Previous studies suggest a larger Nile branch close to Kom el-Gir, an ancient settlement hill in the northwestern Nile Delta. To contribute new knowledge to this little-known site and prove this hypothesis, this study aims at using small-scale paleogeographic investigations to reconstruct an ancient channel system in the surroundings of Kom el-Gir. The study pursues the following: (1) the identification of sedimentary environments via stratigraphic and portable X-ray fluorescence (pXRF) analyses of the sediments, (2) the detection of fluvial elements via electrical resistivity tomography (ERT), and (3) the synthesis of all results to provide a comprehensive reconstruction of a former fluvial network in the surroundings of Kom el-Gir. Therefore, auger core drillings, pXRF analyses, and ERT were conducted to examine the sediments within the study area. Based on the evaluation of the results, the study presents clear evidence of a former channel system in the surroundings of Kom el-Gir. Thereby, it is the combination of both methods, 1-D corings and 2-D ERT profiles, that derives a more detailed illustration of previous environmental conditions which other studies can adopt. Especially within the Nile Delta which comprises a large number of smaller and larger ancient settlement hills, this study's approach can contribute to paleogeographic investigations to improve the general understanding of the former fluvial landscape.

Kurzfassung: Der derzeitige Stand der Forschung über antike Siedlungen im Nildelta erlaubt es, Hypothesen fluvialer Verbindungen zu antiken Siedlungen im gesamten Nildelta aufzustellen. Frühere Studien deuten auf einen größeren Nilarm in der Nähe des Kom el-Girs, einem antiken Siedlungshügel im nordwestlichen Nildelta, hin. Um neue Erkenntnisse zu dieser wenig bekannten Stätte zu gewinnen und diese Hypothese zu beweisen, zielt diese Studie auf kleinräumige paläogeographische Untersuchungen zur Rekonstruktion eines antiken Kanal-/Rinnensystems in der Umgebung des Kom el-Girs ab. Die Studie verfolgt: (1) die Identifizierung von Sedimentationsmilieus mittels stratigraphischer und pXRF- 
Analysen, (2) den Nachweis fluvialer Strukturen mittels elektrischer Widerstandsmessung (ERT) und (3) die Synthese aller Ergebnisse, um eine umfassende Rekonstruktion eines ehemaligen fluvialen Netzwerkes in der Umgebung des Kom el-Girs zu erstellen. Dazu wurden Rammkernsondierungen, pXRF-Analysen und elektrische Widerstandsmessungen (ERT) durchgeführt, um die Sedimente innerhalb des Untersuchungsgebietes zu beschreiben. Die Auswertung der Ergebnisse zeigt deutliche Hinweise auf ein ehemaliges Kanal-/Rinnensystem in der Umgebung des Kom el-Girs. Dabei ist es die Kombination beider Methoden, der 1D-Bohrungen und 2D-ERT-Profile, die eine detailliertere Darstellung früherer Umweltbedingungen ermöglicht und die von anderen Studien übernommen werden kann. Besonders im Nildelta mit seiner großen Anzahl kleinerer und größerer antiker Siedlungshügel, kann der Ansatz dieser Studie in weiteren paläogeographischen Untersuchungen Anwendung finden, um das allgemeine Verständnis ehemaliger Flusslandschaften zu verbessern.

\section{Introduction}

The Nile Delta (Fig. 1) has been settled and cultivated since the Neolithic period as the earliest known archeological remains within the delta from ca. 4530 BCE reveal (Butzer, 2002). The connection of ancient settlements to former Nile branches is considered an essential factor for the vitality of a settlement to supply people and animals with fresh water, to irrigate fields, or as a connection to the transport system (Bietak, 1975; Lange et al., 2016; Schiestl, 2018; Ginau et al., 2019). Therefore, elevated levees or relict dunes near watercourses offered favorable conditions to settle due to the combination of assured protection from the annual Nile flood while providing access to water supply (Wunderlich, 1989; El Gamili et al., 2001; Schiestl, 2018). Based on a high-resolution TanDEM-X image, Ginau et al. (2019) presented the first detailed illustration of a former fluvial landscape (Fig. 2) in the regional context of the northwestern Nile Delta. Kom el-Gir (KeG), an ancient settlement site in the area of interest (Figs. 2, 3), presumably represents a favored place with a hypothesized connection to a larger former Nile branch (Schiestl, 2019). To prove this assumption, this study aims to explore the subsurface sediments in the surroundings of $\mathrm{KeG}$ to obtain a comprehensive view of the paleoenvironmental conditions in this area. In this context, core drillings are widely adopted for scientific investigations into paleoenvironmental reconstructions (Marriner et al., 2012; Pint et al., 2015; Morhange et al., 2016; Seeliger et al., 2018). In addition to core drillings, electrical resistivity tomography (ERT) offers great opportunities for near-subsurface investigations in general (Toonen et al., 2018; Wunderlich et al., 2018) and was previously applied within the Nile Delta (El Gamili et al., 1994, 2001).

Therefore, the study applies a combination of methods to

1. identify and classify sedimentary environments (e.g., riverbed/channel, floodplain) via coring followed by portable X-ray fluorescence (pXRF) analyses of sampled sediments
2. detect fluvial elements (e.g., channel, levee, floodplain) along transects via electrical resistivity tomography (ERT)

3. interpret and correlate all results to combine the pointlike coring data with the two-dimensional data of the ERT in order to derive a reconstruction of a former channel system.

\section{Study area}

\subsection{Geographical setting}

$\mathrm{KeG}$ is located in the northwestern Nile Delta, approx. $20 \mathrm{~km}$ south of Lake Burullus and $16 \mathrm{~km}$ east of the Rosetta branch (Figs. 1, 2). It represents a former settlement hill with a present-day extent of approx. $20 \mathrm{ha}$ and a maximum elevation of ca. $5 \mathrm{~m}$ above the Nile Delta floodplain.

The lithology of the Nile Delta floodplain is characterized by alluvial accumulations dominated by late Neo-Nile deposits (Bilqas Formation), which are overlying the Pre-Nile sediments (Mit Ghamr Formation) at greater depths (Rizzini et al., 1978; Pennington et al., 2017; Gebremichael et al., 2018). Today's uppermost deposits, the so-called Nile mud, represent aggrading clastic sediments that mainly originated as Nile alluvium from the Ethiopian Highlands during the Holocene. Within the delta, the predominantly clayey and silty sediments reach a thickness of $10-15 \mathrm{~m}$ (Andres and Wunderlich, 1986; Wunderlich, 1988, 1989; Woodward et al., 2015; Ginau et al., 2019). These sediments overlie deposits, which mainly consist of fine to medium sands. They are distinguished from the overlying sediments by lighter colors and the appearance of a post-sedimentary lime formation within the upper section. This lime formation was dated by Wunderlich (1989) and verified the sedimentation during the Pleistocene (Wunderlich, 1989; El Gamili et al., 1994).

\subsection{Historical background of $\mathrm{KeG}$}

Recent investigations of the kom's area and pottery from the surface and from corings on the site date the settlement from 


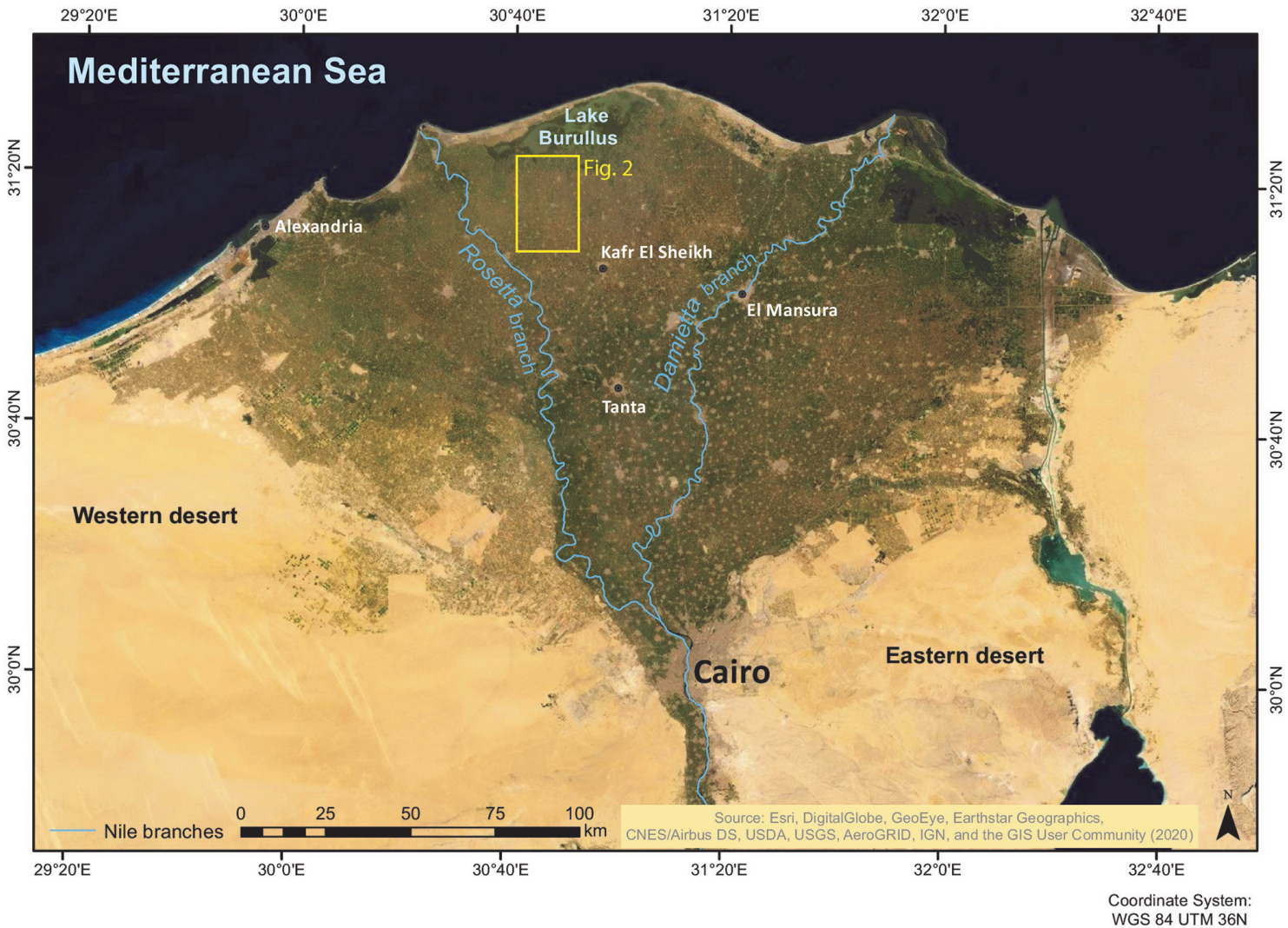

Figure 1. Regional area of interest (yellow frame) located in the northwestern Nile Delta.

the Ptolemaic (late 4th-1st century BCE) to the Late Roman period (4th-7th century CE) (Schiestl, 2012; Schiestl and Herbich, 2013; Schiestl, 2019). Investigations via magnetic prospection further revealed a densely occupied settlement covered with buildings 8 to $10 \mathrm{~m}$ wide as well as additional bigger enclosures. Those are interpreted as a temple enclosure and a Late Roman fort (Schiestl and Rosenow, 2016). Within the Nile Delta, it is the first archeological evidence for the existence of a Roman fort (Schiestl and Herbich, 2013; Schiestl, 2015, 2019). As transport by ship was common during those days, the presumed function and given knowledge about the founding of former settlements support the hypothesis that $\mathrm{KeG}$ was connected to a substantial watercourse (Ginau et al., 2019; Schiestl, 2019).

\section{Material and methods}

To combine and correlate the results of all applied methods, lateral and vertical changes in the subsurface sediment stratigraphy were investigated performing auger core drillings, followed by pXRF analyses of the core sediments as well as electrical resistivity tomography (ERT) measurements.

\subsection{Geoarcheological fieldwork}

Auger core drillings were performed using a vibracorer (Wacker EH 23/230) with open steel auger heads of 8, 6, and $5 \mathrm{~cm}$ diameter and $1 \mathrm{~m}$ length. The drillings reached a maximum depth of $11 \mathrm{~m}$. These recorded the Holocene sedimentary sequence, which normally has a thickness of less than $10 \mathrm{~m}$ (Wunderlich and Andres, 1991). The positions of each drilling location to the north and east of $\mathrm{KeG}$ (Fig. 3) were based on prior investigations of Ginau et al. (2019) and measured using a global navigation satellite system (Topcon GR-5, accuracy of $\leq 2 \mathrm{~cm}$ in all three dimensions). The altitude given in $\mathrm{m}$ a.s.l. (meters above recent sea level) is based on the local reference system, established by the German Archaeological Institute (in German, Deutsches Archäologisches Institut - DAI) and its excavation team of Buto (Ginau et al., 2019). Retrieved sediments were lithologically described via grain size and lime content $(10 \% \mathrm{HCl})$ estimations according to German soil classification (Ad-Hoc-AG Boden, 2005). In addition to this, color (Munsell soil color charts) and special findings (ceramic fragments, mollusks, shell fragments, charcoal, plant remains, etc.) were documented. Based on the specific sedimentological characteristics of the core material, bulk samples for laboratory analyses were taken from the open sediment cores. 


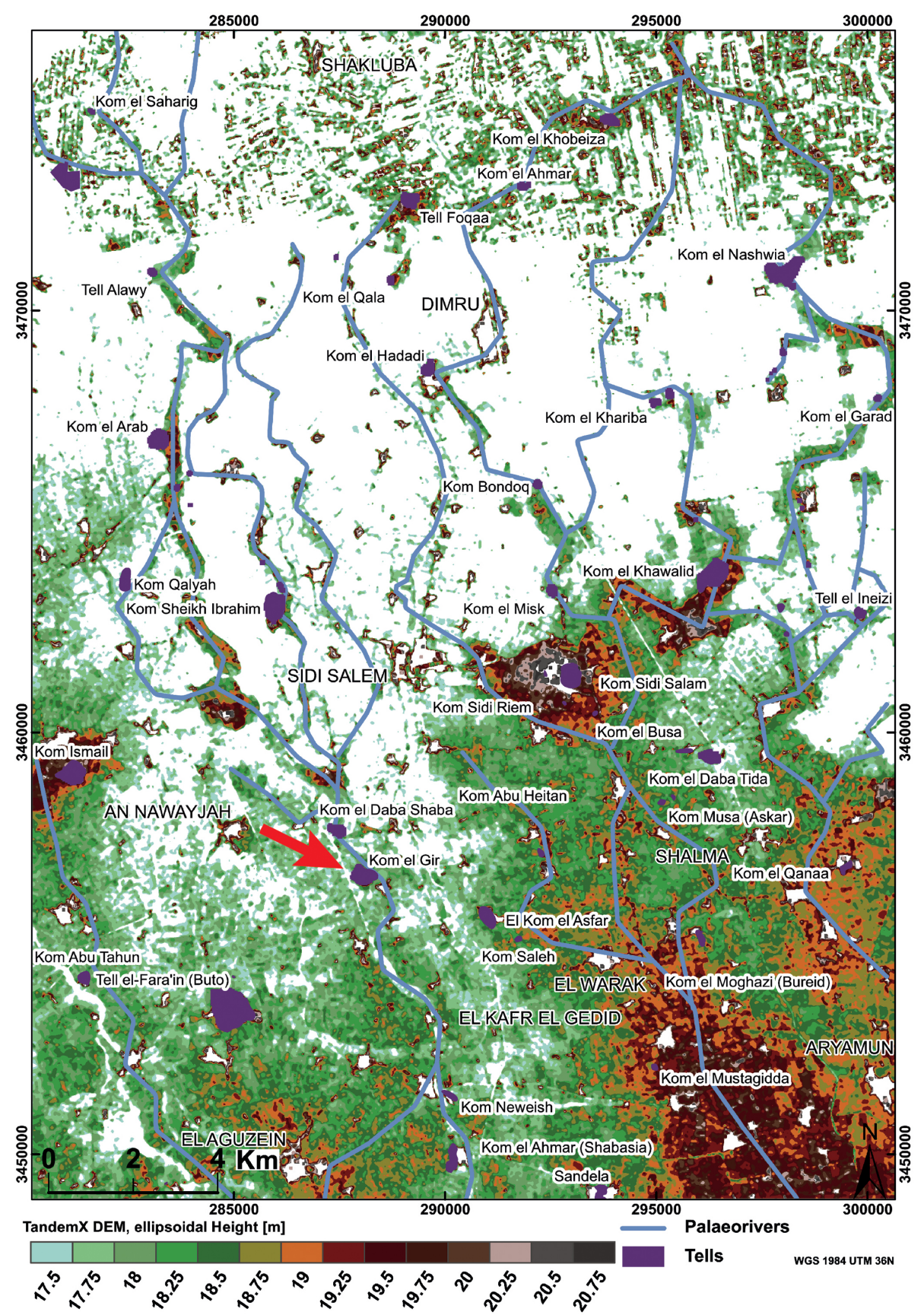

Figure 2. TanDEM-X image of the regional area of interest in the northwestern Nile Delta. The red arrow highlights Kom el-Gir (Ginau et al., 2019; German Aerospace Center).

\subsection{Geochemical analysis via pXRF}

All sample preparation procedures for the subsequent $\mathrm{pXRF}$ analyses adhered to a standardized process flow to reduce the influences on the samples, especially due to missing laboratory facilities and equipment on-site. For each core sample, a reduced sediment mass representing a mix of the overall sample was dried in an oven at $100^{\circ} \mathrm{C}$ for at least $12 \mathrm{~h}$. To produce a homogenous, fine-grained powder, the dried sam- ples were ground in an agate mortar. Through this approach, the results of the conducted pXRF analysis are representative and a true achievement of the respective geochemical signals of the sample is ensured. The ground sample powder was packed into a special XRF plastic cylinder and coated with a $4 \mu \mathrm{m}$ thick XRF foil that allows the best penetration of the fluorescence radiation (Ginau et al., 2019). The sediment samples were analyzed using a Niton XL3t 980-He portable XRF (pXRF) device equipped with an Ag anode. 


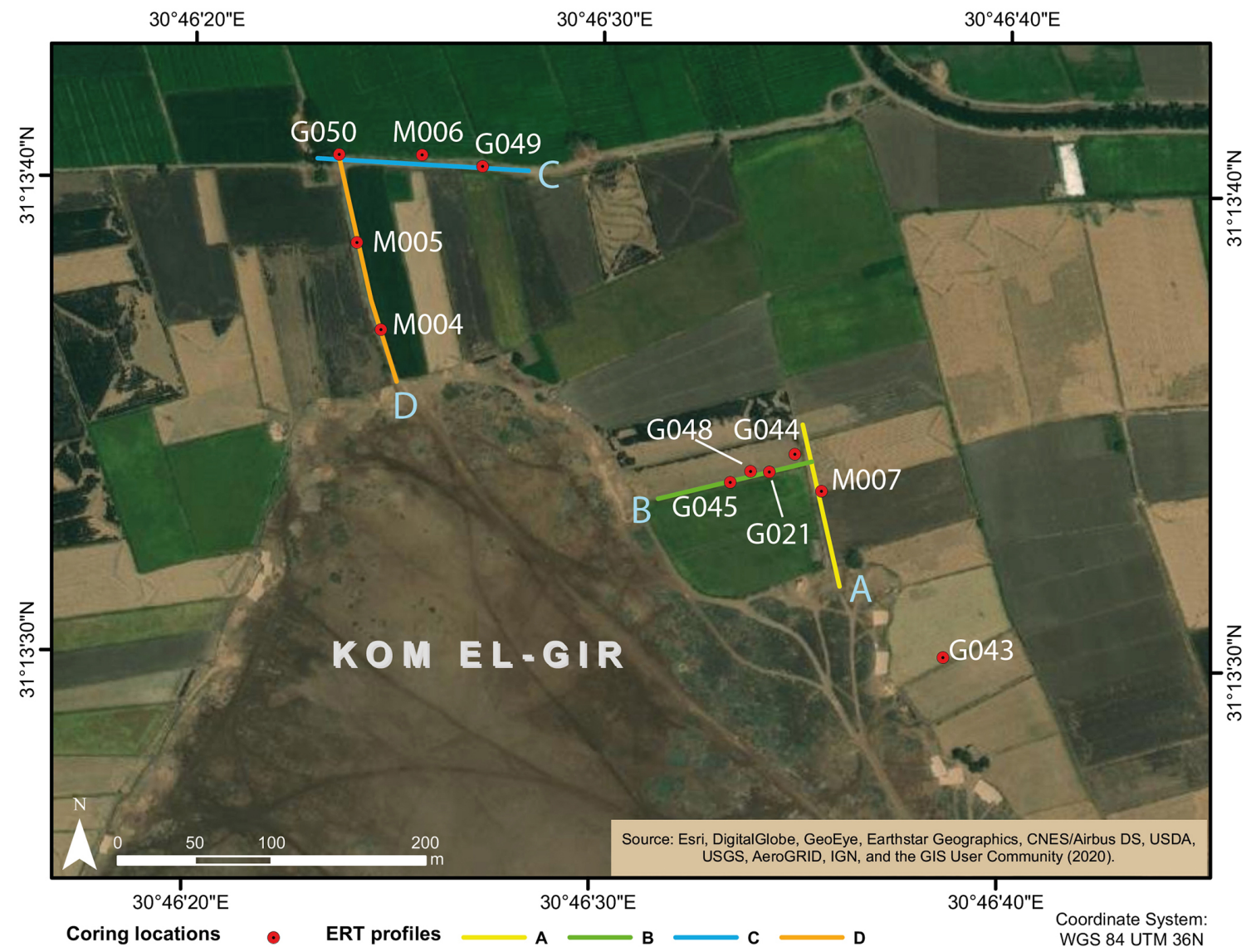

Figure 3. Locations of performed corings and ERT profiles within the study area located north and northeast of KeG.

The measurements were performed under standardized conditions using a measurement chamber. According to testing and calibration within prior research work, the measurement parameters were set to $180 \mathrm{~s}$ using the AllGeo mode that combines the soil and mining mode of the device. During measurements, helium was induced into the detector unit of the device. The application of helium allows the reduction of the measurement times and preserves the necessary precision for the detection of light elements such as phosphor (Ginau et al., 2020).

\subsection{Data analysis}

In addition to the applied methods performed on-site, possible sources of error were considered in order to prepare and analyze the sampled data. Therefore, zero values or values below the limit of detection (LOD), which occur due to the inaccurate precision of the measurement method, were excluded according to the calculated detection limits of Ginau et al. (2020). Based on relevant literature and given geochemical signals used in paleoenvironmental studies (Kern et al., 2019), specific elements or element ratios were selected as potential proxies (Table 1).

\subsection{Electrical resistivity tomography (ERT)}

In total, four profiles (100-150 m length) of electrical resistivity measurements reaching from the edges of $\mathrm{KeG}$ into the adjacent fields were made employing a multi-electrode setup with 24 electrodes using Lippmann 4point light HP equipment. This was considered the appropriate method to detect lateral facies changes down to sounding depths of ca. $10 \mathrm{~m}$. The resistivity distribution was determined by inversions according to the Levenberg-Marquardt algorithm. The profiles were placed alongside the positions of recently performed corings (Fig. 3) to correlate the results of both applied methods. Profiles A-C are presented in Fig. 5, whereas profile D was excluded due to problems during the measurements.

\section{Results}

To investigate the study area, seven corings were performed in the northern and northeastern surroundings of $\mathrm{KeG}$ (Fig. 3). Due to the small extent of the study area and resulting resemblance of the retrieved core sediments, coring M006 is presented exemplarily in detail (Fig. 4). 
Table 1. Selected elements used as geochemical proxies.

\begin{tabular}{|c|c|c|}
\hline Element & Proxy for & Corresponding references \\
\hline $\mathrm{Zr}$ & terrigene influence & Eckert (2014) \\
\hline $\mathrm{Fe}, \mathrm{Al}$ & $\begin{array}{l}\text { fluvial influence (strongly enriched in Blue Nile } \\
\text { draining), terrigenous origin }\end{array}$ & $\begin{array}{l}\text { Vött et al. (2002), Revel et al. (2010), Eckert (2014), } \\
\text { Pint et al. (2015), Pennington et al. (2019) }\end{array}$ \\
\hline $\mathrm{Fe}, \mathrm{S}$ & reducing/anoxic conditions & $\begin{array}{l}\text { Revel et al. (2010), Eckert (2014), Martinez-Ruiz et } \\
\text { al. (2015), Pennington et al. (2019), } \\
\text { Emmanouilidis et al. (2020) }\end{array}$ \\
\hline $\mathrm{Ca}$ & eolian deposit & Woronko (2012) \\
\hline $\mathrm{Cu}$ & anthropogenic influence & Pint et al. (2015), Delile et al. (2018) \\
\hline \multicolumn{3}{|c|}{ Element ratio } \\
\hline $\mathrm{Ca} / \mathrm{Fe}$ & $\begin{array}{l}\text { dominating terrestrial (or fluvial) influences } \\
\text { (in favor of iron) }\end{array}$ & Pint et al. (2015) \\
\hline $\mathrm{Ca} / \mathrm{Ti}$ & $\begin{array}{l}\text { relative contributions of eolian (in favor of } \mathrm{Ca} \text { ) } \\
\text { vs. fluvial (in favor of Ti) input }\end{array}$ & $\begin{array}{l}\text { Vött et al. (2002), Blanchet et al. (2015), } \\
\text { Pint et al. (2015), Castañeda et al. (2016), } \\
\text { Pennington et al. (2019) }\end{array}$ \\
\hline $\mathrm{Cu} / \mathrm{Zn}$ & $\begin{array}{l}\text { nature of river sediments (natural watercourses } \\
\text { vs. human-constructed canals) }\end{array}$ & Ginau et al. (2019) \\
\hline
\end{tabular}

\subsection{Coring M006}

M006 (31.22794 ${ }^{\circ} \mathrm{N}, 30.773801^{\circ} \mathrm{E} ; 2.178 \mathrm{ma.s.1.,}$ depth: $11 \mathrm{~m}$ ) is situated approx. $135 \mathrm{~m}$ north of the northern edge of the present-day kom area (Figs. 3, 4). The lowermost sediments between 11.00 and $6.00 \mathrm{~m}$ b.s. (meters below modern surface) are made of well-sorted silty medium sand, associated with ceramic fragments and mica. The $\mathrm{pXRF}$ values of this section reveal strongly fluctuating $\mathrm{Ca} / \mathrm{Fe}$ and $\mathrm{Ca} / \mathrm{Ti}$ ratios and $\mathrm{Fe}$ and $\mathrm{Al}$ concentrations. The $\mathrm{S}$ concentration of the lowermost section is around $250 \mathrm{ppm}$ with an increasing trend towards upper sections. The $\mathrm{Cu} / \mathrm{Zn}$ ratio shows strong fluctuations between 0.0 and 2.0 while the $\mathrm{Zr}$ concentration fluctuates around $320 \mathrm{ppm}$ up to ca. $3.00 \mathrm{~m}$ b.s.

Between 6.00 and $2.70 \mathrm{mb}$ b.s, the sediment sequence shows alternating layers $(\mathrm{mm}-\mathrm{cm})$ of silty fine sand and medium sand. The intercalation of $\mathrm{fS}$ and $\mathrm{mS}$ shows more fluctuations in the element ratios with a high peak $(2.7$ for $\mathrm{Ca} / \mathrm{Fe}$ and 9.0 for $\mathrm{Ca} / \mathrm{Ti}$ ) in favor of $\mathrm{Ca}$ at approx. $4.50 \mathrm{~m}$ b.s. $\mathrm{Fe}$ and $\mathrm{Al}$ concentrations remain fluctuating before values reveal a gradual increasing trend from $4.00-2.70 \mathrm{~m}$ b.s. After an $\mathrm{S}$ peak of $500 \mathrm{ppm}$, the values gradually decrease with a few anomalies. Only within the upper fS unit is no $\mathrm{S}$ concentration detected. The $\mathrm{Cu} / \mathrm{Zn}$ ratio as well as $\mathrm{Zr}$ further fluctuates until $3.00 \mathrm{~m}$ b.s. where the $\mathrm{Zr}$ concentration begins to increase gradually.

Within the overlying material $(2.70-1.70 \mathrm{~m}$ b.s.), silty fine sand dominates the sediment sequence. The $\mathrm{Ca} / \mathrm{Fe}$ and $\mathrm{Ca} / \mathrm{Ti}$ ratios consistently range around $0.5(\mathrm{Ca} / \mathrm{Fe})$ and 3.0 $(\mathrm{Ca} / \mathrm{Ti})$, while the $\mathrm{Fe}$ and $\mathrm{Al}$ concentrations are generally high with a gradual increase towards the upper sediment section. In contrast to lower core sections, the $\mathrm{Cu} / \mathrm{Zn}$ ratio shows slightly fewer variations and weaker amplitudes. At $1.90 \mathrm{~m}$ b.s., the $\mathrm{Zr}$ concentration reaches its maximum of approx. $680 \mathrm{ppm}$ within the uppermost Ufs unit.

Between 1.70 and $1.00 \mathrm{mb}$ b.s., silty fine sand within the lower section gradually transitions into fine sandy silt towards the upper parts. In contrast to underlying sections, these sediments reveal a medium lime content of $\mathrm{c} 1-\mathrm{c} 3$. Between 2.00 and $0.30 \mathrm{~m}$ b.s., the $\mathrm{S}$ concentration ranges around 0 and $350 \mathrm{ppm}$.

The uppermost material ( $1.00-0.30 \mathrm{~m}$ b.s.) consists of clay intercalated by silty clay, showing decreasing $\mathrm{Ca} / \mathrm{Fe}$ and $\mathrm{Ca} / \mathrm{Ti}$ ratios in favor of $\mathrm{Ca}$, while $\mathrm{Fe}$ and $\mathrm{Al}$ concentrations gradually increase. The $\mathrm{Zr}$ concentration reveals gradually decreasing values around $240 \mathrm{ppm}$.

\subsection{ERT profiles}

The ERT profiles measured the electrical resistivity of the subsurface sediments over a length of 100-150 and 8-10 m depth with a total resistivity range from less than $2.5 \Omega \mathrm{m}$ to approx. $40.0 \Omega \mathrm{m}$ (Figs. 3, 5).

The lowest resistivity $(<2.5-10.0 \Omega \mathrm{m})$ was predominantly measured within the topmost subsurface sediments, partially reaching into deeper surface areas and occurring as lenses (Fig. 5a, b). Medium values of electrical resistivity (10.0 $20.0 \Omega \mathrm{m}$ ) are observed within various profile areas. They are present within middle profile sections as well as within neartell areas. Sediments of higher electrical resistivity (20.0 $40.0 \Omega \mathrm{m}$ ) are predominantly located below the top layer of low resistivity and within deeper profile sections. They 


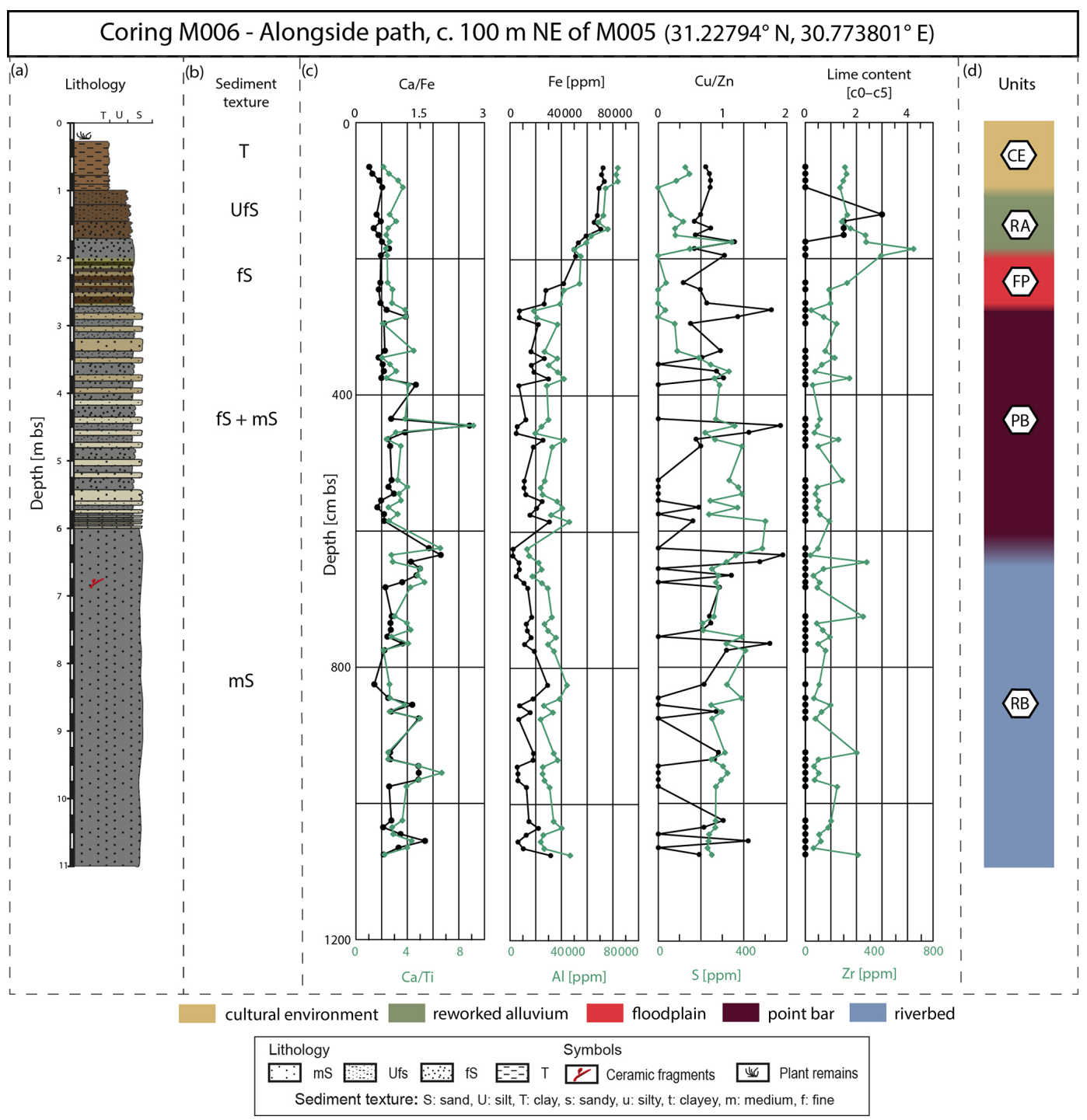

Figure 4. Lithostratigraphy (a) and sediment texture (b) as well as pXRF results of selected proxies (c) for coring M006. For unit interpretation (d) see Sect. 5 .

mainly occur as depressions representing channel-like features.

\subsection{ERT profile C}

In addition to coring M006 (Fig. 4), ERT profile C (Fig. 5c), which includes the coring site of M006, is exemplarily described in detail. The modeled ERT image is subdivided into three sections, showing distinct differences in electrical resistivity of the sediments. The material of the uppermost $1.50 \mathrm{~m}$ b.s. reveals low to medium resistivity values $(5.0$ $11.0 \Omega \mathrm{m}$ ), reaching further down to $4.00 \mathrm{~m}$ b.s. within the western profile part. Sediments below this layer reveal high electrical resistivity $(20.0-40.0 \Omega \mathrm{m})$, almost visible over the entire profile length and depth. Only between profile meters 20 and 50 does the material within the lowermost $2 \mathrm{~m}$ pos- sess lower resistivity values around $10.0 \Omega \mathrm{m}$. Besides, the material of high resistivity is sharply defined by sediments with medium $(15.0-16.0 \Omega \mathrm{m})$ resistivity. The boundary of medium values is visible in the top transition area and lowerlying parts.

\section{Discussion}

\subsection{Interpretation and discussion of core data}

\subsubsection{Classification of sedimentary units}

Based on the coring results, eight distinct units (Fig. 6) are identified that represent the sedimentary environments in which the sediments once accumulated or that predominantly influenced them. 

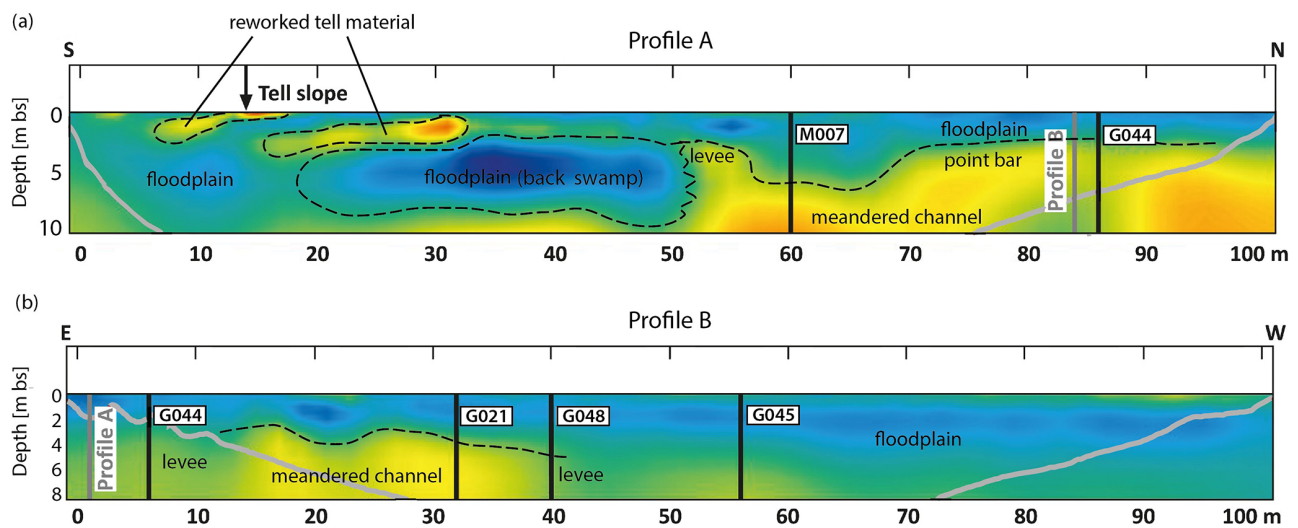

(c)

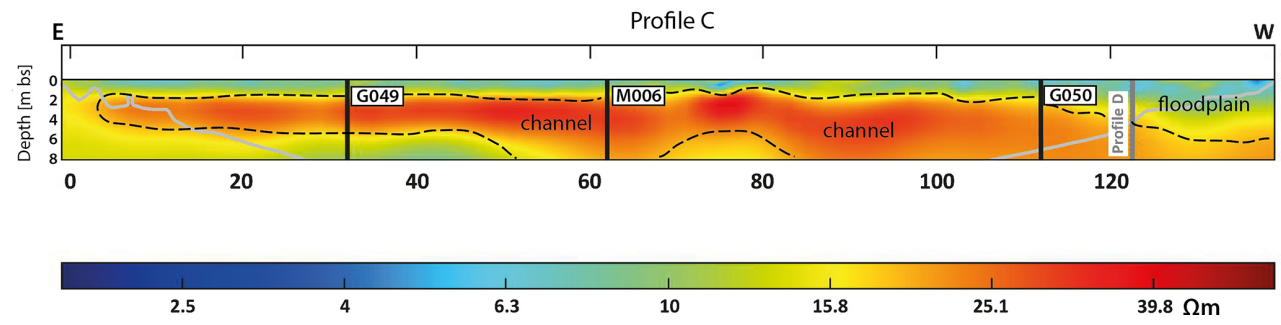

Figure 5. Modeled ERT images of (a) profile A, (b) profile B, and (c) profile $\mathrm{C}$ with identified subsurface channel elements. The color scale visualizes the resistivity of the subsurface sediments, ranging from blue, representing low resistivity to red, representing high resistivity. Further features such as locations of several corings conducted in this area are also indicated. The grey lines mark the boundaries of uncertain result reliability towards the start and end of the profile. For profile location see Fig. 3.

- Unit BA (basement). The dark grey to whitish colored fine to medium sands (Fig. 6a, b) with partially horizontal color shifts to greenish and yellowish hues indicate former fluvial origin. Studies of regional sediments show that those deposits are usually overlain by peat or organic-rich layers and reveal elevated lime concentrations within upper parts (Wunderlich, 1989; Ginau et al., 2019).

- Unit LE (levee). The yellowish-brown coarser sandy sediments are intercalated with thin, fine-grained dark brown loam layers (Fig. 6d). Those sediment alternations are interpreted as a result of flood events with gradually decreasing flow velocities within areas adjacent to channels. The periodical flood sediments accumulated as darker and fine-grained layers in between the sandy deposits, shaping elevated overbank structures (Wunderlich, 1989; Toonen et al., 2012; El Bastawesy et al., 2020). A trend of increasing sediment accumulation is also reflected by gradually increasing $\mathrm{Zr}$ concentrations, which mainly originate from erosional processes, reflecting the terrigenous character of the sediments (Eckert, 2014). Furthermore, alternating flood and drought phases are reflected by intense fluctuations in the $\mathrm{Cu} / \mathrm{Zn}$ ratio (Ginau et al., 2019).

- Unit RB (riverbed). The grey-colored material (Fig. 6e) with partially greenish to dark olive hues varies be- tween fine-grained sediments and coarse sand, associated with findings of ceramic fragments, pebbles, or mollusks which serve as proxies for a former channel environment (Giaime et al., 2018; Ginau et al., 2019). $\mathrm{The} \mathrm{Ca} / \mathrm{Ti}$ and $\mathrm{Ca} / \mathrm{Fe}$ ratios in favor of $\mathrm{Ti}$ and $\mathrm{Fe}$, additionally indicate former fluvial conditions (Pint et al., 2015; Castañeda et al., 2016; Croudace et al., 2019; Pennington et al., 2019). Fe with its terrigenous origin is strongly enriched in the sediments transported by the Blue Nile, possibly fed by erodible Fe-rich silicate rocks present within the Ethiopian drainage basin (Revel et al., 2010; Ménot et al., 2020). Continuous fluctuations in the measured pXRF data underline the fluvial nature of this unit. The geochemical variability reveals changing streamflow conditions associated with alternating floods and droughts (Stanley et al., 2003; Ginau et al., 2019).

- Unit PB (point bar). The dark greenish-grey as well as light whitish coarser sediments are strongly laminated with dark grey to greyish-brown silts (Fig. 6c). The elements and associated ratios show a similar geochemical variability to those of unit RB. Fluctuations within the $\mathrm{Fe}$ and $\mathrm{Al}$ concentrations as well as the $\mathrm{Cu} / \mathrm{Zn}$ ratio indicate the accumulation within a fluvial system (Stanley et al., 2003; Ginau et al., 2019). The visible lamination of the sand section with silty strata highlights changing hydrodynamics (Vött et al., 2002; Goiran et al., 2014). 


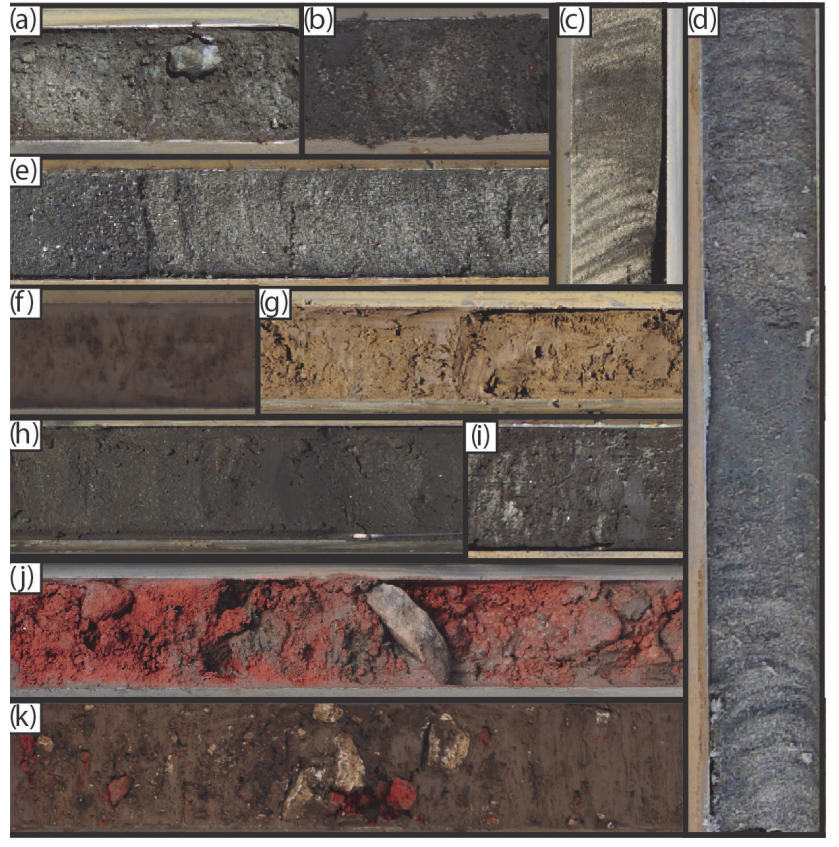

Figure 6. Exemplary core sediments corresponding to the different sedimentary units. Selected sediments of the coring material representing the identified units. (a, b) unit basement, (c) unit point bar, (d) unit levee, (e) unit riverbed, (f, g) unit reworked alluvium, (h, i) unit floodplain, (j) unit cultural debris, and (k) unit cultural environment.

The $\mathrm{Ca} / \mathrm{Fe}$ and $\mathrm{Ca} / \mathrm{Ti}$ ratios show peaks towards $\mathrm{Ca}$, indicating predominantly eolian input at certain intervals (Woronko, 2012; Blanchet et al., 2015; Pint et al., 2015; Pennington et al., 2019). Partially present high S concentrations reflect the existence of reducing conditions, detectable within silty sediments corresponding to phases of low-energy flow or stagnant water (Goiran et al., 2014; Martinez-Ruiz et al., 2015).

- Unit FP (floodplain). The light brown to greenish-grey and dark grey varying sediments range from clay to coarser sand (Fig. 6h, i). The small-scale layering of multiple accumulated sections of silty clay and medium sand indicates a change in the energetic environmental conditions caused either by variations in sediment load and flood height or by alternating channel courses and associated marginalizing energetic conditions. The fluctuating $\mathrm{Cu} / \mathrm{Zn}$ ratio reflects phases of floods and droughts (Stanley et al., 2003; Ginau et al., 2019). A partially elevated lime content, the $\mathrm{Ca} / \mathrm{Ti}$ ratio in favor of $\mathrm{Ca}$, and plant remains support the assumption that sediments were accumulated within an area of dominating eolian input during dryer periods (Woronko, 2012; Pint et al., 2015). During warm and dry periods without flood events, ascendant water mobilization possibly led to Ca precipitation (Vött et al., 2002; Pennington et al., 2019). The fine-grained material is partially rich in organics characterized by a distinct sulfidic smell and a blackish color, which developed due to the existence of a long-lasting brackish water body (Wunderlich, 1989; Ginau et al., 2019). Coarser sediments either were accumulated within close distance of an active channel or can be interpreted as crevasse splays, transported over longer distances from the stream course due to the higher streamflow velocity of flood events (Wunderlich, 1989; Toonen et al., 2012; Ginau et al., 2019).

- Unit CD (cultural debris). The red-brick-colored composition of brick and ceramic fragments (Fig. 6j) shows distinct boundaries of under- and overlying sediments. Although, the unit can be clearly distinguished visually, differences in its geochemistry compared to the overlying reworked alluvium (see unit RA) are not detectable.

- Unit RA (reworked alluvium). The dark yellowishbrown clayey to fine sandy material (Fig. 6f, g) represents the Nile alluvium characteristic for this region (Wunderlich, 1989; Ginau et al., 2019). High element loadings of $\mathrm{Fe}$ and $\mathrm{Al}$, indicating that the deposited sediments are fluvially transported material with a terrigenous origin, underline the presumed source (Revel et al., 2010; Eckert, 2014; Pint et al., 2015; Pennington et al., 2019). The unit contains cultural components such as charcoal, ceramic, and brick fragments that presumably influenced the sediment's geochemistry and altered the geochemical signal, leading to differing geochemical distributions and elemental loadings compared to those of a floodplain area without human influences. Thus, the sediments of this unit rather show steady to gradual element distributions. The visible gradual increase in element loadings, such as $\mathrm{Fe}$ and $\mathrm{Al}$, without severe geochemical distinctions, further indicate anthropogenic influences (Ginau et al., 2017, 2019; Pennington et al., 2019).

- Unit CE (cultural environment). The dark greyishbrown sediments composed of varying amounts of clay, silt, and fine sand (Fig. 6k) are predominantly formed by human activity. A high quantity of anthropogenic remains such as ceramic or brick fragments, charcoals, mortar, and plastic bags among other findings such as plant remains, lime concretions, and pebbles are present.

\subsubsection{Interpretation of coring M006}

The results of core M006 (Fig. 4) lead to a differentiation of five units (Fig. 7). The lowermost unit (11.00-6.00 m b.s.) is represented by unit $\mathrm{RB}$. The presence of a ceramic fragment embedded within coarse sand underlines a sediment transport by a turbulent flow (Goiran et al., 2014). The overlying sediments (6.00-2.80 m b.s.) are attributed to unit PB. A visible lamination within the sediment texture and the coarse 
material underlines this interpretation. The material above (2.80-2.00 m b.s.) is identified as unit FP. The existence of fine sand and the number of color differences within the sediments suggest a fluvial origin, presumably with minor distance to the actual channel stream (Toonen et al., 2020). The sediments above (2.00-1.25 m b.s.) are transitioning into unit RA. Although no anthropogenic remains are visible, increasing $\mathrm{Fe}$ and $\mathrm{Al}$ concentrations and the depth of the unit within the drilling core indicate anthropogenic influences. The uppermost material $(1.25-0.00 \mathrm{~m}$ b.s.) predominantly shows strongly enriched $\mathrm{Fe}$ and $\mathrm{Al}$ concentrations without the presence of ceramic fragments or other remains as well. Nevertheless, it is to be identified as unit CE, considering the core location and implied influences of human activity.

\subsection{Interpretation of ERT profile C}

The images of all three ERT profiles (Fig. 5) reveal clear indicators for buried channel features. Specifically, the resistivity distribution of profile C (Fig. 5c) shows two deep structures with high values (at 55-70 and 80-120 m), presumably representing relict riverbeds as channel sediments contain fine to coarser sand (Ginau et al., 2019). A zone of medium resistivity values (at 70-80 m) in lower-profile sections leads to the interpretation of a sand/point bar between the two channels.

Lower hydrodynamics within such stream-protected areas entail dominating accumulation processes. An alternating streamflow leads to the deposition of sediments with varying grain sizes. The lithological character of the deposits most likely reveals laminations of coarse and fine-grained sediments (Wunderlich, 1989; Goiran et al., 2014; Toonen et al., 2018). Thus, due to the portions of coarse-grained material, the electrical resistivity potentially reveals higher values as well. High ERT values above this presumed sand/point bar indicate overlying channel deposits. Therefore, a first channel construction with two branches and a corresponding sand bar in between is assumed. A potential increasing discharge may have initiated the extending of these streams into one wider channel (channel Ia) that also incorporates the area between $10-50 \mathrm{~m}$ (Fig. 5c). However, the eastern half of the profile may also represent a floodplain close to the detected channel. The slightly decreasing electrical resistivity towards the eastern profile end may correspond to the decrease in the mean deposit grain size with distance to an active stream (Toonen et al., 2020). Following this idea, a corresponding floodplain on the western edge at approx. $120-140 \mathrm{~m}$ is to be expected.

\subsection{Channel-network reconstruction}

The obtained data distinctively reveal evidence of buried channel elements embedded in the subsurface sediments of the study area. The core sediments of M006 and the ERT profile $\mathrm{C}$ reveal the presence of coarse sand sequences that reach from near-surface areas (approx. $3.00 \mathrm{~m}$ b.s.) to deeper sections. These deep-reaching coarse deposits could only have been accumulated within a stream course with high hydrodynamics and flow velocity (Wunderlich, 1989; Goiran et al., 2014). Further corings (M004, M005) in this area also comprise coarse-grained sediments within deeper sections that are classified as unit RB according to their lithology and pXRF data (Fig. 7). In addition to this, M004 incorporates a preserved FP unit below the riverbed section, indicating lower hydrodynamics, which only partially eroded these floodplain deposits. Therefore, it is to be assumed that the location of coring M004 represents marginal areas of the former channel environment. The identified sedimentary units (unit PB and unit FP) within upper sections of M004 and M005 indicate the channel relocation towards the north. Thereby, the interpretations of the ERT profile $\mathrm{C}$ lead to the assumption that this profile cuts the former channel nearly orthogonally, indicating the presence of an additional stream.

This presumption is revised with the aid of the topographic map of the Survey of Egypt (Fig. 8) that presents contour lines in this area. At the considered location, the contour lines are narrower, which indicates a slightly steeper slope (Fig. 8). A potentially increasing flow energy of the channel may have initiated a further discharge course. Within deeper sections of the ERT profile, two identified depressions suggest the first initiation of two smaller streams before extending into one larger stream. Based on the ERT and coring results, revealing near-surface locations of these channel elements, it is assumed that the channel (channel Ia) silted up later than the channel incorporating M004 and M005 (channel Ib).

The northeast-located corings and ERT measurements also reveal evidence of a former channel (channel II).

Based on the interpretation of the ERT profiles A and B (Fig. 5a, b), the stream is interpreted as a smaller side channel. Although the dimensions of the defunct paleochannel cannot be drawn with certainty, the interpretations of the results lead to this schematic reconstruction (Fig. 8). In consideration of the corings G044 and G048, the pXRF data of the sediments furthermore indicate a low-energy stream. They also align with additional results by Ginau et al. (2019), concluding there was a former channel (coring G21 Fig. 5b) in the eastern surroundings of KeG. Based on its infill comprising loamy fine sand, the authors attributed the stream to a low-energy domain that also revealed characteristics of a natural channel (Ginau et al., 2019). In addition to this, the existent RB units within the performed corings transitioning into FP units and the thickness of these sections suggest an earlier siltation than in the northern channel.

The applied multi-proxy approach allowed the small-scale reconstruction of a former channel system within the study area. However, the sole use of a pXRF approach may be problematic as the Nile Delta sediments possess strong conformities regarding their chemical composition. This can be explained by the consistent sources of the Nile sediments, which did not vary due to climate fluctuations or human in- 


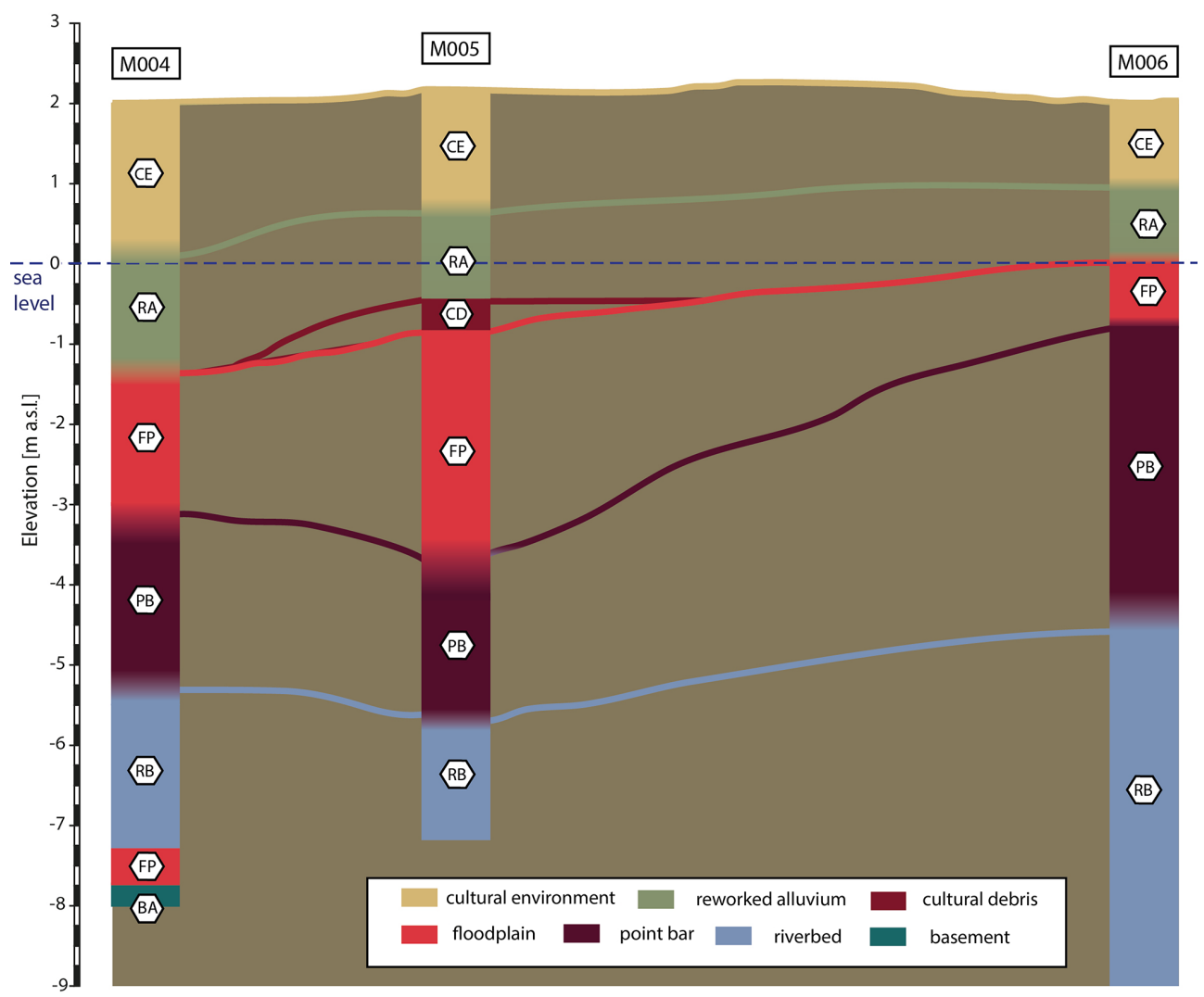

Figure 7. Identified units of coring M004, M005, and M006 representing the environmental evolution in this part of the study area. Corings are presented schematically; for core locations see Fig. 3.

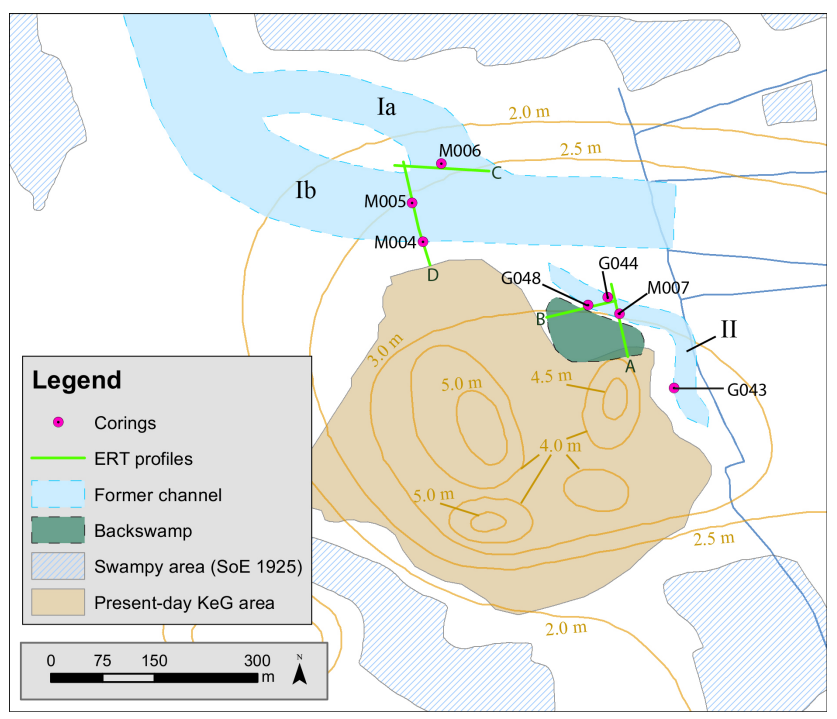

Figure 8. Reconstructed channel systems in the northern and northeastern surroundings of KeG. Based on topographic map of the Survey of Egypt from 1925 (scale $1: 25000$ ). fluences. Thus, the pXRF values within this study are only to be considered in combination with the lithological sediment description. However, additional studies may further develop this multi-proxy approach and add more sedimentary and geochemical analyses to the state of research.

\section{Conclusion}

Through the pXRF analyses of the coring material, eight sedimentary environments are classified that provide subsequent insights into the evolution of the coring sites and former environmental conditions of the study area.

These analyses and the ERT images reveal clear evidence for deposits of defunct channels in the area close to $\mathrm{KeG}$. While deep-reaching sandy deposits in the northern research area represent a former stream (channel Ia, Ib) with high hydrodynamics, the northeast-located sediments show only features of a smaller channel (channel II) with lower flow velocity. In summary, by combining pXRF analyses, lithology, and ERT measurements, a comprehensive small-scale reconstruction of a former fluvial network was elaborated in the area northeast of KeG. Therefore, combining these methods yields a massive benefit in answering the assumptions of Schiestl (2019) about the Nile Delta's fluvial landscape. The 
used approach may be a choice for investigations of several other settlement hills in the nearby area (Fig. 2).

Although the pXRF analyses and ERT measurements provide no indications of the width of the former streams, topographic maps and current satellite images suggest a framework for the potential dimensions of at least one of the identified channels by the arrangement of fields southeast of KeG. Furthermore, due to a lack of dating facilities, it is not possible to relate the channels to each other or the period of their activity. In this context, future research may provide improved reconstructions and extended insights regarding this topic and the illustrated channel network as well as its dimensions. Datings, microfossil analyses, and further multi-proxy approaches may contribute additional knowledge about the channel system and their activity periods.

Data availability. The TanDEM-X digital elevation model is used with the permission of the German Aerospace Center (DLR), based on the data requested via the proposal (DEM_HYDR1426) by Andreas Ginau, Robert Schiestl, Jürgen Wunderlich, Eva LangeAthinodorou, and Tobias Ullmann.

All further data generated during this study are included in this article or are available from the corresponding author upon request.

Author contributions. MA, MS, and JW designed this study. All authors performed the fieldwork, mainly comprising drilling, sediment sampling, and leveling the coring locations via GNSS. AG, MA, and MS carried out the pXRF analyses. MA wrote the first draft of the manuscript that was later improved by all co-authors. MA created all figures. JW acquired the funding for this research. RS provided the archeological and historical background for this paper.

Competing interests. The authors declare that they have no conflict of interest.

Special issue statement. This article is part of the special issue "Geoarchaeology of the Nile Delta". It is a result of the workshop "Geoarchaeology of the Nile Delta: Current Research and Future Prospects”, Würzburg, Germany, 29-30 November 2019.

Acknowledgements. The fieldwork was conducted as part of the regional survey around Buto (Tell el-Fara'in), with a particular focus on Kom el-Gir. This project is undertaken under the auspices of the Cairo Department of the German Archaeological Institute (DAI). We thank Viktor Nawa and Mona Maier-Rotter for performing the ERT measurements. Thanks to the entire DAI team, especially the first director of the DAI Cairo Department Stephan Seidlmayer for his hospitality and support during the field campaigns. We thank the Egyptian Ministry of State for Antiquities for their assistance and support of our work in the field and for granting the research permits. Furthermore, we thank the two anonymous reviewers for their valuable comments.

Financial support. This study was funded by the Deutsche Forschungsgemeinschaft (DFG, German Research Foundation) (grant no. 392434407).

This open-access publication was funded by the Goethe University Frankfurt.

Review statement. This paper was edited by Tobias Ullmann and reviewed by two anonymous referees.

\section{References}

Ad-Hoc-AG Boden: Bodenkundliche Kartieranleitung, Bundesanstalt für Geowissenschaften und Rohstoffe in Zusammenarbeit mit den Staatlichen Geologischen Diensten, 5, Hannover, Germany, 2005.

Andres, W. and Wunderlich, J.: Untersuchungen zur Paläogeographie des westlichen Nildeltas im Holozän, Marburger Geographische Schriften, 100, 117-131, 1986.

Bietak, M.: Tell el-Dab'a II: Der Fundort im Rahmen einer archäologisch-geographischen Untersuchung über das ägyptische Ostdelta, Verlag d. Österr. Akademie d. Wissenschaft, Vienna, Austria, 1975.

Blanchet, C. L., Contoux, C., and Leduc, G.: Runoff and precipitation dynamics in the Blue and White Nile catchments during the mid-Holocene: A data-model comparison, Quaternary Sci. Rev., 130, 222-230, https://doi.org/10.1016/j.quascirev.2015.07.014, 2015.

Butzer, K. W.: Geoarchaeological Implications of Recent Research in the Nile Delta, in: Egypt and the Levant. Interrelations from the 4th throught the early 3rd Millennium B.C.E., New Approaches to Anthropological Archaeology, edited by: van den Brink, E. C. M. and Levy, T. E., Leicester University Press, London/New York, 83-97, 2002.

Castañeda, I. S., Schouten, S., Pätzold, J., Lucassen, F., Kasemann, S., Kuhlmann, H., and Schefuß, E.: Hydroclimate variability in the Nile River Basin during the past 28,000 years, Earth Planet. Sc. Lett., 438, 47-56, https://doi.org/10.1016/j.epsl.2015.12.014, 2016.

Croudace, I. W., Löwemark, L., Tjallingii, R., and Zolitschka, B.: Current perspectives on the capabilities of high resolution XRF core scanners, Quatern. Int., 514, 5-15, https://doi.org/10.1016/j.quaint.2019.04.002, 2019.

Delile, H., Goiran, J. P., and Blichert-Toft, J.: The contribution of geochemistry to ancient harbor geoarcheology: The example of Ostia Antica, Quaternary Sci. Rev., 193, 170-187, https://doi.org/10.1016/j.quascirev.2018.06.019, 2018.

Eckert, S.: The past and present trace metal budget of the Black Sea: a comparison of the Holocene and Eemian marine ingression, PhD thesis, Carl von Ossietzky Universität, University Oldenburg, Germany, 120 pp., 2014.

El Bastawesy, M., Gebremichael, E., Sultan, M., Attwa, M., and Sahour, H.: Tracing Holocene channels and land- 
forms of the Nile Delta through integration of early elevation, geophysical, and sediment core data, The Holocene, https://doi.org/10.1177/0959683620913928, 2020.

El Gamili, M. M., Shaaban, F. F., and El-Morsi, O. A.: Electrical resistivity mapping of the buried stream channel of the Canopic Branch in the Western Nile Delta, Egypt, J. Afr. Earth Sci., 19, 135-148, https://doi.org/10.1016/0899-5362(94)90046-9, 1994.

El Gamili, M. M., Ibrahim, E. H., Hassaneen, A. R. G., Abdalla, M. A., and Ismael, A. M.: Defunct Nile Branches Inferred from a Geoelectric Resistivity Survey on Samannud area, Nile Delta, Egypt, J. Archaeol. Sci., 28, 1339-1348, https://doi.org/10.1006/jasc.2001.0761, 2001.

Emmanouilidis, A., Messaris, G., Ntzanis, E., Zampakis, P., Prevedouros, I., Bassukus, D. A., and Avramidis, P.: CT scanning, X-ray fluorescence: Non-destructive techniques for the identification of sedimentary facies and structures, Revue de micropaléontologie, 67, 100410, https://doi.org/10.1016/j.revmic.2020.100410, 2020.

Gebremichael, E., Sultan, M., Becker, R., El Bastawesy, M., Cherif, O., and Emil, M.: Assessing land deformation and sea encroachment in the Nile Delta: a radar interferometric and inundation modeling approach, J. Geophys. Res.-Sol. Ea., 123, 3208-3224, https://doi.org/10.1002/2017JB015084, 2018.

Giaime, M., Morhange, C., Marriner, N., López-Cadavid, G. I., and Artzy, M.: Geoarchaeological investigations at Akko, Israel: New insights into landscape changes and related anchorage locations since the Bronze Age, Geoarchaeology, 33, 641-660, https://doi.org/10.1002/gea.21683, 2018.

Ginau, A., Schiestl, R., Kern, F., and Wunderlich J.: Identification of historic landscape features and settlement mounds in the Western Nile Delta by means of remote sensing time series analysis and the evaluation of vegetation characteristics, J. Archaeol. Sci.: Reports, 16, 170-184, https://doi.org/10.1016/j.jasrep.2017.09.034, 2017

Ginau, A., Schiestl, R., and Wunderlich J.: Integrative geoarchaeological research on settlement patterns in the dynamic landscape of the northwestern Nile delta, Quatern. Int., 511, 51-67, https://doi.org/10.1016/j.quaint.2018.04.047, 2019.

Ginau, A., Steiniger, D., Hartmann, R., Hartung, U., Schiestl, R., Altmeyer, M., Seeliger, M., and Wunderlich, J.: What settlements leave behind - pXRF compositional data analysis of archaeological layers from Tell el-Fara'in (Buto, Egypt) using machine learning, Palaeogeogr. Palaeocl., 546, 109666, https://doi.org/10.1016/j.palaeo.2020.109666, 2020.

Goiran, J. P., Salomon, F., Mazzini, I., Bravard, J. P., Pleuger, E., Vittori, C., Boetto, G., Christiansen, J., Arnaud, P., Pellegrino, A., Pepe, C., and Sadori, L.: Geoarchaeology confirms location of the ancient harbour basin of Ostia (Italy), J. Archaeol. Sci., 41, 389-398, https://doi.org/10.1016/j.jas.2013.08.019, 2014.

Kern, O. A., Koutsodendris, A., Mächtle, B., Christanis, K., Schukraft, G., Scholz, C., Kotthoff, U., and Pross, J.: XRF core scanning yields reliable semiquantitative data on the elemental composition of highly organic-rich sediments: Evidence from the Füramoos peat bog (Southern Germany), Sci. Total Environ., 697, 134110, https://doi.org/10.1016/j.scitotenv.2019.134110, 2019.

Lange, E., Ullmann, T., and Baumhauer, R.: Remote sensing in the Nile Delta: spatio-temporal analysis of Bubastis/Tell Basta,
Egypt and the Levant, 26, 377-392, available at: https://www. jstor.org/stable/44243959 (last access: 10 August 2020), 2016.

Marriner, N., Flaux, C., Kaniewski, D., Morhange, C., Leduc, G., Moron, V., Chen, Z., Gasse, F., Empereur, J. Y., and Stanley, J.D.: ITCZ and ENSO-like pacing of Nile delta hydro geomorphology during the Holocene. Quaternary Sci. Rev., 45, 73-84, https://doi.org/10.1016/j.quascirev.2012.04.022, 2012.

Martinez-Ruiz, F., Kastner, M., Gallego-Torres, D., RodrigoGámiz, M., Nieto-Moreno, V., and Ortega-Huertas, M.: Paleoclimate and paleoceanography over the past 20,000 yr in the Mediterranean Sea Basins as indicated by sediment elemental proxies, Quaternary Sci. Rev., 107, 25-46, https://doi.org/10.1016/j.quascirev.2014.09.018, 2015.

Ménot, G., Pivot, S., Bouloubassi, I., Davtian, N., Hennekam, R., Bosch, D., Ducassou, E., Bard, E., Migeon, S., and Revel, M.: Timing and stepwise transitions of the African Humid Period from geochemical proxies in the Nile deepsea fan sediments, Quaternary Sci. Rev., 228, 106071, https://doi.org/10.1016/j.quascirev.2019.106071, 2020.

Morhange, C., Giaime, M., Marriner, N., abu Hamid, A., Bruneton, H., Honnorat, A., Kaniewski, D., Magni, F., Porotov, A. V., Wante, J., Zviely, D., and Artzy, M.: Geoarchaeological evolution of Tel Akko's ancient harbor (Israel). J. Archaeol. Sci., 7, 71-81, https://doi.org/10.1016/j.jasrep.2016.03.046, 2016.

Pennington, B. T., Sturt, F., Wilson, P., Rowland, J., and Brown, A. G.: The fluvial evolution of the Holocene Nile Delta, Quaternary Sci. Rev., 170, 212-231, https://doi.org/10.1016/j.quascirev.2017.06.017, 2017.

Pennington, B. T., Hamdan, M. A., Pears, B. R., and Sameh, H. I.: Aridification of the Egyptian Sahara 5000-4000 cal BP revealed from $\mathrm{X}$-ray fluorescence analysis of the Nile Delta sediments at Kom al-Ahmer/Kom Wasit, Quatern. Int., 514, 108-118, https://doi.org/10.1016/j.quaint.2019.01.015, 2019.

Pint, A., Seeliger, M., Frenzel, P., Feuser, S., Erkul, E., Berndt, C., Klein, C., Pirson, F., and Brückner, H.: The environs of Elaia's ancient open harbour-a reconstruction based on macrofaunal evidence, J. Archaeol. Sci., 54, 340-355, https://doi.org/10.1016/j.jas.2014.06.011, 2015.

Revel, M., Ducassou, E., Grousset, F. E., Bernasconi, S. M., Migeon, S., Révillon, S., Mascle, J., Murat, A., Zaragosi, S., and Bosch, D.: 100,000 years of African monsoon variability recorded in sediments of the Nile margin, Quaternary Sci. Rev., 29, 1342-1362, https://doi.org/10.1016/j.quascirev.2010.02.006, 2010.

Rizzini, A., Vezzani, F., Cococcetta, V., and Milad, G.: Stratigraphy and sedimentation of a Neogene - Quaternary section in the Nile Delta area (ARE), Mar. Geol., 27, 327-348, https://doi.org/10.1016/0025-3227(78)90038-5, 1978.

Schiestl, R.: Investigating ancient settlements around Buto, Egyptian Archaeology, 40, 18-20, 2012.

Schiestl, R.: Landschaftsarchäologie und regionale Siedlungsnetzwerke um den Fundplatz Tell el-Fara'in, Gouvernorat Kafr esch-Scheich. Die Arbeiten des Jahres 2012, e-Forschungsberichte, 1, 11-13, available at: https://www.dainst.org/documents/10180/727267/eFB2015-1_ Schiestl_Buto.pdf/cff14d7c-eb23-4be5-bde9-911156900701 (last access: 31 May 2021), 2015.

Schiestl, R.: Gouvernorat Kafr esch-Scheich, Ägypten. Landschaftsarchäologie und regionale Siedlungsnetzwerke um den Fund- 
platz Tell el-Fara'in (Buto) im Nildelta. Die Arbeiten des Jahres 2018, e-Forschungsberichte 2018, 2, 44-46, available at: https://publications.dainst.org/journals/index.php/efb/article/ view/2149 (last access: 24 May 2021), 2018.

Schiestl, R.: Gouvernorat Kafr esch-Scheich, Ägypten. Landschaftsarchäologie und regionale Siedlungsnetzwerke um den Fundplatz Tell el-Fara'in im Nildelta und Untersuchungen am antiken Fundplatz Kom el-Gir. Die Arbeiten des Jahres 2018 und Frühjahres 2019, e-Forschungsberichte, 2, 51-55, https://doi.org/10.5282/ubm/epub.69238, 2019.

Schiestl, R. and Herbich, T.: Kom el-Gir in the western Delta, Egyptian Archaeology, 42, 28-29, 2013.

Schiestl, R. and Rosenow, D.: Prospektion am Kom el-Gir: eine Einführung in eine neue Siedlung des Deltas, Mitteilungen des Deutschen Archäologischen Instituts, Abteilung Kairo, 72, 169196, 2016.

Seeliger, M., Pint, A., Frenzel, P., Weisenseel, P. K., Erkul, E., Wilken, D., Wunderlich, T., Başaran, S., Bücherl, H., Herbrecht, M., Rabbel, W., Schmidts, T., Szemkus, N., and Brückner, H.: Using a multi-proxy approach to detect and date a buried part of the Hellenistic City Wall of Ainos (NW Turkey), Geosciences, 8, 357, https://doi.org/10.3390/geosciences8100357, 2018.

Stanley, J. D., Krom, M. D., Cliff, R. A., and Woodward, J. C.: Short contribution: Nile flow failure at the end of the Old Kingdom, Egypt: strontium isotopic and petrologic evidence, Geoarchaeology, 18, 395-402, https://doi.org/10.1002/gea.10065, 2003.

Toonen, W. H. J., Kleinhans, M. G., and Cohen, K. M.: Sedimentary architecture of abandoned channel fills, Earth Surf. Proc. Land., 37, 459-472, https://doi.org/10.1002/esp.3189, 2012.

Toonen, W. H. J., Graham, A., Pennington, B. T., Hunter, M. A., Strutt, K. D., Barker, D. S., Masson-Berghoff, A., and Emery, V. L.: Holocene fluvial history of the Nile's west bank at ancient Thebes, Luxor, Egypt, and its relation with cultural dynamics and basin-wide hydroclimatic variability, Geoarchaeology, 33, 273290, https://doi.org/10.1002/gea.21631, 2018.

Toonen, W. H. J., Munoz, S. E., Cohen, K. M., and Macklin, M. G.: High-Resolution Sedimentary Paleoflood Records in Alluvial River Environments: A Review of Recent Methodological Advances and Application to Flood Hazard Assessment, in: Palaeohydrology, Geography of the Physical Environment, edited by: Herget, J. and Fontana, A., Springer, Cham, Switzerland, https://doi.org/10.1007/978-3-030-23315-0_11, 213-228, 2020 .
Vött, A., Handl, M., and Brückner, H.: Rekonstruktion holozäner Umweltbedingungen in Arkanien (Nordwestgriechenland) mittels Diskriminanzanalyse von geochemischen Daten, Geologica et Palaeontologica, 36, 123-147, 2002.

Woodward, J., Macklin, M., Fielding, L., Millar, I., Spencer, N., Welsby, D., and Williams, M.: Shifting sediment sources in the world's longest river: A strontium isotope record for the Holocene Nile, Quaternary Sci. Rev., 130, 124-140, https://doi.org/10.1016/j.quascirev.2015.10.040, 2015.

Woronko, B.: Late-Holocene dust accumulation within the ancient town of Marea (coastal zone of the South Mediterranean Sea, N Egypt), Quatern. Int., 266, 4-13, https://doi.org/10.1016/j.quaint.2011.09.010, 2012.

Wunderlich, J.: Investigations on the development of the western Nile Delta in Holocene times, in: The Archaeology of the Nile Delta: Problems and Priorities, edited by: van den Brink, E. C. M., Neth. Found. Archaeol. Res. Egypt, Amsterdam, the Netherlands, 251-257, 1988.

Wunderlich, J.: Untersuchungen zur Entwicklung des westlichen Nildeltas im Holozän, Marburger Geographische Schriften, 114, Marburg/Lahn, Germany, 1989.

Wunderlich, J. and Andres, W.: Late Pleistocene and Holocene evolution of the western Nile delta and implications for its future development, in: Von der Nordsee bis zum Indischen Ozean, Erdkundliches Wissen, edited by: Brückner, H. and Radtke, U., Franz Steiner Verlag, Stuttgart, Germany, 105-120, 1991.

Wunderlich, T., Fischer, P., Wilken, D., Erkul, E., Mecking, R., Günther, T., Heinzelmann, M., Vött, A., and Rabbel, W.: Constraining electric resistivity tomography by direct push electric conductivity logs and vibracores: An exemplary study oft he Fiume Morto silted riverbed (Ostia Antica, western Italy), Geophysics, 83, B87-B103, https://doi.org/10.1190/geo20160660.1, 2018. 